\title{
Anti-androgenic Impact of Nauclea latifolia on Testicular Weight, Testosterone, Follicle Stimulating Hormone and Glycogen Granules of the Testes
}

\author{
Eno-Obong I. Bassey, Gabriel D. Edem, Kingsley A. Okon, and Aquaisua N. Aquaisua
}

\section{ABSTRACT}

Purpose: Over time, plants have been a major source of medicine to treat and cure various ailments and diseases. In many cases, the dosages and standardization of these herbal products have been so ignored that it results in these products causing damages to certain organs of the body unnoticed. The impact of ethanolic leaf extract of Nauclea latifolia on the testes was determined using Wistar rats.

Method: 500, 1000 and $1500 \mathrm{mg}$ of ethanolic leaf extract of Nauclea latifolia $/ \mathrm{kg}$ body weight was administered for 21 days to 4 groups of animals $(\mathrm{n}=10)$. Blood sample was taken for hormonal assay, testicular weight measured, and histological procedure done, and the tissues stained with PAS.

Results: Result from hormonal assay showed reduced level of testosterone and follicle stimulating hormone. After histological staining using periodic acid Schiff method (PAS) and subsequent examination using a compound microscope, there was a reduced level of glycogen granules in all the Nauclea latifolia groups. Findings from this study also showed that the ethanolic leaf extract of Nauclea latifolia at all doses significantly reduced testicular weight $(\mathbf{p}<\mathbf{0 . 0 5})$.

Conclusion: This study reveals that Nauclea latifolia is anti-androgenic.

Keywords: Androgenic, FSH, Glycogen, Testosterone, Nauclea latifolia.
Submitted : June 01, 2021

Published : July 04, 2021

ISSN: 2593-8339

DOI: $10.24018 /$ ejmed.2021.3.4.905

\section{E. I. Bassey"}

Department of Anatomy, College of Health Sciences, University of Uyo, Nigeria.

(e-mail: enobongibassey@uniuyo.edu.ng) G. D. Edem

Department of Anatomy, College of Health Sciences, University of Uyo, Nigeria.

(e-mail: profgabe4sure@gmail.com)

K. A. Okon

Department of Anatomy, College of Health Sciences, University of Uyo, Nigeria.

A. N. Aquaisua

Department of Anatomy, College of

Health Sciences, University of Uyo, Nigeria.

*Corresponding Author

\section{INTRODUCTION}

In spite of the great advances in modern medicine, plants still make an important contribution to healthcare. This is due to the recognition of the value of traditional medicine. Traditional medicine is a comprehensive term used to refer to both traditional medicine systems such as traditional Chinese medicine and to various forms of indigenous medicine [1]. Medicinal plants have various effects on living systems, some of which are analgesic, sedative, antipyretic, cardioprotective, while others have anti-inflammatory, antioxidative, anti-splasmodic and immuno-modulatory functions [2]. In Africa and in Nigeria, most people resort to herbal remedies [1]. This is partly because medicinal plants are affordable and efficacious in the treatment of diseases. Despite advances and availability of orthodox drugs, there is still a high patronage of herbal medicine. Seeking remedies for human ailments from the environment has formed the basis for therapeutics [3]. Traditional medicine is a potential source of new drugs and as a source of cheap starting products for the synthesis of known drugs. Some examples include reserpine from Rauwolfia species and viablastine from Catharanthus roseus [4]. Plants therefore form the major resort for the treatment of diseases and sicknesses by traditional healers in many societies. One of the plants that feature prominently from the ethanobotanical survey in herbal medicine for disease treatment in Nigeria is "Nauclea latifolia". Nauclea latifolia commonly known as pin cushion belongs to the family Rubiaceae. It is a straggling shrub or small tree that is widely distributed in both Savannah and tropical forests of West Africa. It is a versatile African medicinal plant growing in different parts of Nigeria. In Akwa Ibom and Cross River States, it is called "mbom mbon" while in northern Nigeria, it is called "Tabasiya" or African quinine. It is known as "uburu" or "mbitinu" in Igbo, "egbesi" in Yoruba [5]. Nauclea latifolia is used in the treatment of ailments like malaria [6]-[8], gastrointestinal tract disorders [9], sleeping sickness[10], hypertension [11], as a chewing stick [12] and to stop prolonged menstrual flow [13]. It is also used by traditional birth attendants in Nigeria to arrest preterm contractions in pregnant women [14]. In Burkina Faso, the plant is used for the treatment of several diseases like jaundice, infant gastroenteritis, and dysentery [15]. The plant is also used as a tonic and fever medicine, in treatment of toothaches, dental caries, septic mouth and diarrhea [16]. Many commercially proven drugs used in modern medicine were initially used in crude form in traditional or folk healing practices, or for other purposes that suggested potentially useful biological activity [17]. The plant contains several phytochemicals such as alkaloids. Nauclea latifolia is potent 
for treating malaria, gastrointestinal tract disorders and other ailments. Nauclea latifolia leaf extract is locally consumed as an infusion with alcohol. Numerous studies have indicated that alcohol abuse in men can cause impaired testosterone production and shrinkage of the testes or testicular atrophy [18]. This study hopes to assess the effect of ethanolic leaf extract of Nauclea latifolia on the histomorphology of the testes of adult Wistar rats, to evaluate the impact of ethanolic leaf extract of the plant on testicular hormones (testosterone and follicle stimulating hormone) and on testicular weight.

\section{MATERIALS AND METHODS}

\section{A. Source and Maintenance of Animals}

A total of forty (40) adult male Wistar rats weighing between 170 and $260 \mathrm{~g}$ were used for the experiments. The rats were obtained from the Animal House of the College of Health Sciences, University of Uyo, Uyo, Nigeria. The animals were kept in cages with plated lead net as covering and sawed particles as bedding and allowed to acclimatize for 14 days under standard laboratory conditions of temperature $27-30{ }^{\circ} \mathrm{C}$, with photoperiodicity of 12 hours light alternating with 12 hours of darkness. They were fed with commercial rat pellet (Vital Feeds, Grand Cereals Limited, Jos, Nigeria) and allowed access to water ad libitum. All procedures involving animals in this study conformed to the guiding principles for research and were approved by the local Ethical Committee on the use and care of animals [19] in conformity with international acceptable standards.

\section{B. Preparation of Extract}

The leaves of Nauclea latifolia were obtained from a local farm in Nsit Ibom Local Government Area of Akwa Ibom State. The plant was identified by a Botanist in the Department of Pharmacognosy, Faculty of Pharmacy, University of Uyo and authenticated in the Department of Botany, University of Uyo where herbarium specimen number UUH 031/15 was deposited. The freshly harvested leaves of Nauclea latifolia were dried under shade for 7 days. The air-dried leaves were powdered. The leaf powder was macerated in $70 \%$ ethanol (Sigma Aldrich, St. Louis USA) in a flat bottom flask and kept for 72 hours at room temperature. The macerated leaves were filtered, and the filtrate concentrated in water bath at $45^{\circ} \mathrm{C}$ to dryness. Extract was weighed and stored in the refrigerator until required for use.

\section{Experimental Design}

Forty (40) male adult Wistar rats were used for this study. They were randomly divided into four (4) groups designated as control and experimental groups; each group consisted of ten (10) rats each. The treatment lasted twenty-one (21) days to assess the effect of chronic consumption of Nauclea latifolia. Individual animal body weight was recorded daily till the end of the experiment. Group 1 was the control and received $15 \%$ tween $80(10 \mathrm{ml}$ of tween $80 / \mathrm{kg}$ body weight of rats), group 2 received Nauclea latifolia (500 mg of ethanolic leaf extract of Nauclea latifolia $/ \mathrm{kg}$ body weight of rats), group 3 received Nauclea latifolia (1000 mg of ethanolic leaf extract of Nauclea latifolia/kg body weight of rats) and group 4 received Nauclea latifolia (1500 mg of ethanolic leaf extract of Nauclea latifolia/kg body weight of rats).

\section{The Protocol and Necropsy Schedule}

At the end of each experiment, the animals were weighed and sacrificed on the day after the last dose was given. Sacrifice was done under anaesthesia with chloroform vapour. Incisions were made by a ventral laparotomy which was extended into the scrotum. The testes were removed, weighed, and prepared for histological processing. Blood samples were obtained through cardiac puncture by inserting a needle from a syringe into the right auricle. Blood was drawn into the $10 \mathrm{ml}$ syringe and thereafter emptied into ethylene di-amine-tetra-acetic acid (EDTA) and plain sterile plastic bottles. Five (5) milliliters of blood were emptied into the plain bottles and serum separated for hormonal assay.

\section{E. Tissue Processing for Histological Studies-Periodic Acid Schiff Technique for Glycogen}

Sections were deparaffinized in xylene and hydrated to water using descending grades of alcohol, rinsed in water, oxidized in $0.5 \%$ periodic acid solution for 5 minutes, rinsed in distilled water and allowed to react. Sections were placed in Schiff reagent for 15 minutes, washed in lukewarm tap water for 5 minutes. They were counterstained in Mayer's haematoxylin for 1 minute, washed in tap water for 5 minutes, dehydrated and covered with coverslip using dipolycysteine xylene (DPX) mountant.

\section{F. Hormonal Assay}

Hormonal assay was carried out using serum from blood obtained from cardiac puncture and allowed to clot. The samples were assayed in batches from a standardized curve using the Enzyme Linked Immunosorbent Assay (ELISA) method. The microelisa stripplate well kits used were obtained from Sunlong Biotech Co. Ltd, U.S.A. Testosterone and follicle stimulating hormone assays were done using sandwich ELISA method.

\section{G. Statistical Analysis}

All numerical results were analyzed using one-way Analysis of variance (ANOVA) followed by studentNewman Keuls post hoc test to determine difference between control mean and treatment means at significant rate of $\mathrm{P}<$ 0.05 . Data were expressed as mean \pm standard error of mean (SEM).

\section{RESULTS}

\section{A. Morphological Observations}

The testicular weight in gramme obtained in this study were: $4.40 \pm 0.14,2.51 \pm 0.39,1.54 \pm 0.02$ and $1.19 \pm 0.00$ for the control, low dose $(500 \mathrm{mg} / \mathrm{kg})$ body weight of ethanolic leaf extract of $N$. latifolia, medium dose $(1000 \mathrm{mg} / \mathrm{kg})$ and high dose $(1500 \mathrm{mg} / \mathrm{kg})$ body weight of ethanolic leaf extract of $N$. latifolia groups respectively. Findings from this study showed that the ethanolic leaf extract of Nauclea latifolia at all doses significantly reduced testicular weight $(\mathrm{p}<0.05)$. 


\section{B. Periodic Acid Schiff Technique Showing Glycogen Granules among the Groups}

The Periodic Acid Schiff Technique (PAS) section of the testes of control rats given tween 80 showed prominent seminiferous tubules with intense staining of the basement membrane and numerous spermatids close to the lumen at magnification X 400. The spermatids showed positivity for PAS (Fig. 1). The section of the testis of the experimental rats administered $500 \mathrm{mg}$ of ethanolic leaf extract of $N$. latifolial $\mathrm{kg}$ body weight of rats showed seminiferous tubules with intense staining of basement membrane and mainly secondary spermatocytes and spermatids closed to the lumen. The spermatids show intense positivity for PAS (Fig. 2) but few glycogen granules. In the testes of the experimental rats administered $1000 \mathrm{mg}$ ofethanolic leaf extract of $N$. latifolia/ $\mathrm{kg}$ body weight of rats, the section showed prominent seminiferous tubules containing proliferating germinal cells with intensely stained basement membrane, intense staining of secondary spermatocytes and spermatids with positivity for PAS (Fig. 3). Section of the testes of experimental rats administered $1500 \mathrm{mg}$ of ethanolic leaf extract of $N$. latifolia/kg body weight of rats showed prominent seminiferous tubules with intact basement membrane showing intense staining of the basement and the lumen filled with degenerative tissues and scanty spermatids with less intensity (Fig. 4). The results are represented in the photomicrographs below.

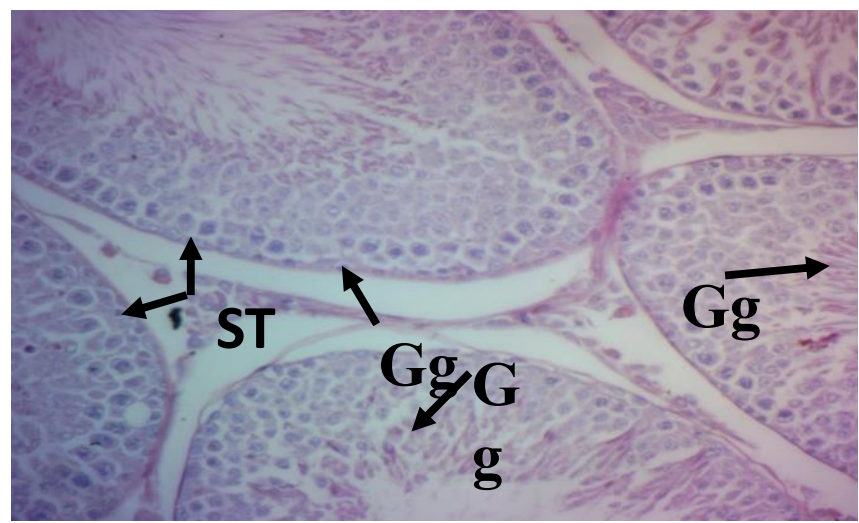

Fig. 1. Photomicrograph of the Testis of rats in control group $(10 \mathrm{ml}$ of $15 \%$ tween $80 / \mathrm{kg}$ body weight of rats) showing intensely stained glycogen granules $(\mathrm{Gg})$ and basement membrane (PAS X 400).

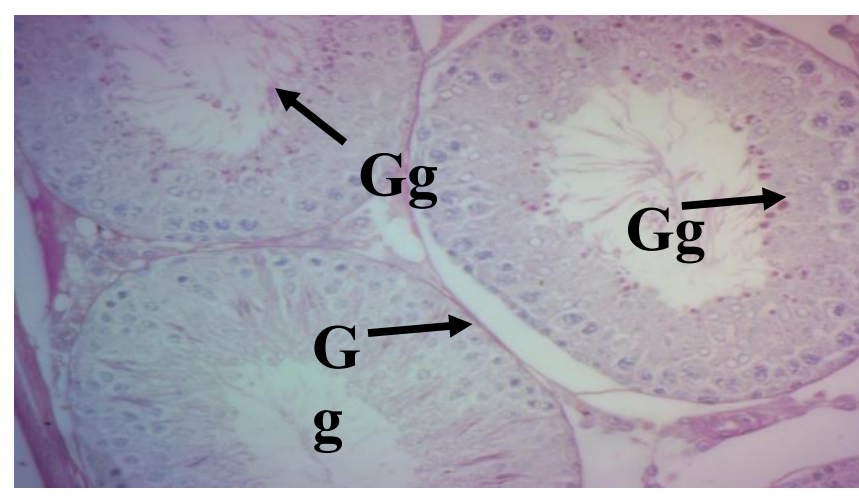

Fig. 2. Group 2 (low dose $-500 \mathrm{mg}$ of ethanolic leaf extract of Nauclea latifolia $/ \mathrm{kg}$ body weight of rats) showing few but intensely stained Glycogen granules $(\mathrm{Gg})$ and deeply stained basement membrane of the seminiferous tubules (ST) (PAS X 400).

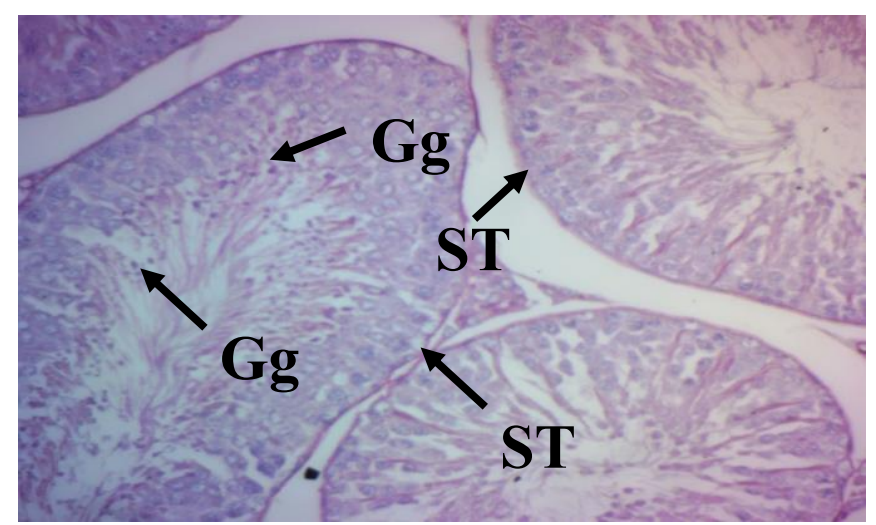

Fig. 3. Group 3(middle dose-1000mg of ethanolic leaf extract of N. latifolia/kg body weight of rats) showing intensely stained Glycogen granules $(\mathrm{Gg})$ and intensely stained basement membrane of the seminiferous tubules (ST) (PAS X 400).

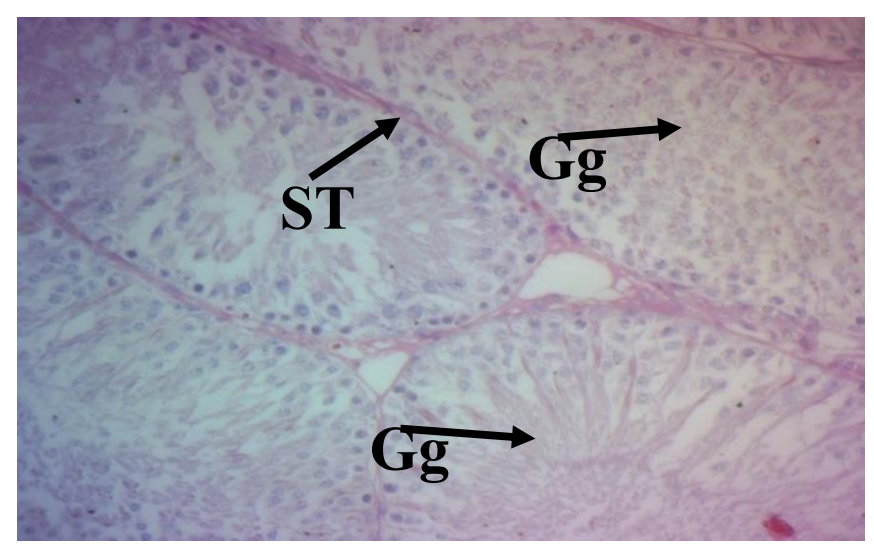

Fig. 4. Group 4 (high dose-1500mg of ethanolic leaf extract of Nauclea latifolia/kg body weight of rats) showing less staining intensity of glycogen granules $(\mathrm{Gg})$ and intensely stained basement membrane of the seminiferous tubules (ST) (PAS X 400).

\section{DISCUSSION}

The testes are well-equipped with powerful intrinsic defense systems that protect the spermatozoa during its spermatogenic and post spermatogenic journey and from injuries caused by other intrinsic or extrinsic factors. Nevertheless, the testis is one of the organs that is very vulnerable to assault. Morphological observations revealed a significant reduction in testicular weight of adult rats administered 500, 1000 and $1500 \mathrm{mg}$ of ethanolic leaf extract of Nauclea latifolia. The decrease in testicular weight was dose-dependent, the highest reduction occurred in the group administered $1500 \mathrm{mg}$ of ethanolic leaf extract of Nauclea latifolia. The decreased in testicular weight in these groups may have occurred as a result of the presence of alkaloid which is a bioactive component in Nauclea latifolia. Alkaloid causes damage to germ cells and seminiferous tubules [20]. The mechanism of alkaloids effect is to increase lipid peroxidation in testis and cause activation of caspase 3 and apoptotic proteins in testicular germ cells [21]. The weight of all the testicular samples harvested from rats fed with ethanolic leaf extract of Nauclea latifolia were reduced to statistically significant levels when compared to control, indicating a widespread damage which could be ascribed to alkaloid and a decrease in protein content of the testis. The reaction in the periodic acid Schiff technique is a true histochemical method, showing oxidation of carbohydrate 
with periodic acid to liberate aldehydes which restore the colour of Schiff reagent. The aldehyde liberated recoloured the basic fuschin that had been rendered colorless as leucofuschin which is finally coloured and appeared magenta red. Glycogen is a form of carbohydrate in which animals store their energy in the tissue. Testes that have undergone loss of activation usually have low capacity of glycogen content and the oxidative ability increased. The result of the periodic acid Schiff technique showing the distribution of glycogen granules among the experimental groups administered different doses of ethanolic leaf extract of $N$. latifolia showed few Glycogen granules in the group administered $500 \mathrm{mg}$ of ethanolic leaf extract of $N$. latifolia $/ \mathrm{kg}$ body weight of rats. The Glycogen granules in the group administered $1000 \mathrm{mg}$ of ethanolic leaf extract of $N$. latifolia $/ \mathrm{kg}$ body weight of rats was moderate shown mostly in the secondary spermatocytes and spermatids. In the PAS section of testis of rats given $1500 \mathrm{mg}$ of ethanolic leaf extract of $N$. latifolia $/ \mathrm{kg}$ body weight of rats, the staining intensity of the cells was less, as a result of degeneration and hyalinized germinal cells. This implies that at high dose Nauclea latifolia lowers the glycogen content of the testis. The glycogen granules were found mostly in the basement membrane in the spermatids due to the presence of proacrosomal granules and in the secondary spermatocytes. The result of this study also showed that there was a significant reduction of the serum level of follicle stimulating hormone in adult male rats administered 500, 1000 and 1500 $\mathrm{mg}$ of ethanolic leaf extract of Nauclea latifolia $/ \mathrm{kg}$ body weight of rats. This suggests that Nauclea latifolia may act as follicle stimulating hormone antagonist. Reduction in the level of follicle stimulating hormone involves metabolizing bound follicle stimulating hormone receptors (FSHR) sites, internalization, sequestration, and degradation of hormonereceptor complexes in lysosomes or reduced receptor protein synthesis [22]. The bound FSH-receptor complex is brought about by lateral migration of this unit into a "coated pit" where such units are concentrated and stabilized by a framework of clathrins and finally internalized and degraded by lysosomes. Binding of follicle stimulating hormone to its receptor alters its conformation leading to insertion of sulfotyrosine by follicle stimulating hormone receptor. This leads to transduction of signal that activates the glycoprotein bound to the receptor internally, which detaches from the receptor and activates the (cyclic Amp-dependent Kinases) (cAMP) system [23]. The binding of FSH to the receptor shifts the equilibrium between active and inactive receptors. FSH and FSH-agonists shift the equilibrium in favour of active states, while the FSH antagonists shift the equilibrium in favour of inactive states. Cyclic AMP dependent protein kinases (protein kinase A) are activated by the signal chain coming from the $\mathrm{G}$ protein activated by the $\mathrm{FSH}$ receptor via Adenylate cyclase and cyclic AMP (cAMP). These protein kinases consist of regulatory units and catalytic units [24]. Upon binding of cAMP to the regulatory units, the catalytic units are released and initiate the phosphorylation of proteins leading to the physiologic action of FSH. These activated kinases phosphorylate the receptor [25]. The longer the receptor remains active, the more kinases are activated, and the more receptors are phosophorylated. FSH acts on sertoli cells resulting in the production of androgen-binding protein, which helps in the passage of testosterone through sertoli and sertoli functional complexes. This process is critical for the initiation of spermatogenesis. Therefore, any agent that damages the viability and function of sertoli cells as Nauclea latifolia appeared to in this study may have profound effect on the level of FSH and spermatogenesis. Diminished secretion of FSH can result in hypogonadism.It is evident that testosterone is involved in maintenance of spermatogenesis, in the development of spermatogonia to spermatocytes and also in stimulation of the spermatogenic process [26], [27]. It is also known that sperm production cannot proceed to optimal completion without a continuous androgen supply [28]. The result from this study demonstrated that Nauclea latifolia caused a reduction in serum testosterone level. This could be linked to a decrease in the rate of spermatogenesis and may be associated with a lower than normal testosterone level. Testosterone serum level showed significant reduction in the sections of testis of rats administered 500, 1000 and $1500 \mathrm{mg}$ of ethanolic leaf extract of Nauclea latifolia $/ \mathrm{kg}$ body weight of rats. This reduction was dose dependent. The results of this study highlight that the ethanolic leaf extract of Nauclea latifolia have anti-androgen effect. Anti-androgens inhibit circulating androgens by blocking androgen receptors and suppressing androgen synthesis [29]. The most common anti-androgens are androgen receptor (AR) antagonists which act on the target cell level and competitively bind to androgen receptors. Anti-androgen also suppresses androgen synthesis by inhibiting cytochrome p450 and 17, 20-lyase which is involved in synthesis and degradation of steroids, including the precursors of testosterone; this results in a decrease in the level of testosterone [30]. Anti-androgens can also suppress gonadotropin secretion by down-regulating gonadotropin releasing hormone receptor (GnRHR) in the pituitary gland [31]. Suppression of GnRHRs results in inability of gonadotropin-releasing hormone $(\mathrm{GnRH})$ to bind sufficiently. GnRH is responsible for the release of the gonadotropin luteinizing hormone $(\mathrm{LH})$. LH stimulates the leydig cells of the testes to produce testosterone. Therefore, If GnRH cannot bind; testosterone synthesis is not induced in testes.

\section{CONCLUSION}

Ethanolic leaf extract of Nauclea latifolia significantly decreased the level of glycogen in the testes. The hormonal assay in this study revealed a decrease in the serum concentration of testosterone and follicle stimulating hormone.

\section{REFERENCES}

[1] World Health Organization. The Promotion and Development of Traditional Medicine. Geneva: Technical Report Series, 622. 2002.

[2] D.E. Okwu, V. Ezenagu, Evaluation of the Phytochemical Composition of Mango (Mangifera indica Linn) Stem, Bark and Leaves. International Journal of Chemical Science, 6(2): 705-716. 2008.

[3] P. Potier, L. Mangatal, M.T. Le Goff, V.F. Querittle, O. Guenard, F. Lavelle. Relationships Between the Structure of Taxol Analogues and their Anti-biotic Activity. Journal of Medical Chemotherapy, 34, 992998. 1990

[4] A. Sofowora. Medicinal Plants and Traditional Medicine in Africa, $2^{\text {nd }}$ edition, Ibadan, Nigeria. Spectrum Books Ltd, p. 130.1993. 
[5] Morah F.N.I. Morah. Naucleaidal and Epinaucleidal from Anti-viral Preparation from Nauclea latifolia Jamaican Journal of Science and Technology, 5, 22-24. 1994.

[6] J.O. Kokwaro. Medicinal Plants of East Africa. Nairobi. East Africa Literature Bureau.1976; p. 35.

[7] P. I, Akabue, G.C. Mittal Clinical Evaluation of a Traditional Herbal Practice in Nigeria, Preliminary Report. Journal of Ethnopharmacology, 6(3): 355-359. 1982.

[8] G.L. Boye. Studies on Antimalarial Action of Cryptolepsis Sanguinolenta Extract. Procedures on International Symposium. 1990; 41, 243-251.

[9] W. Maduabunyi. Anti-hepatoxic and Trypanocidal Activities of the Ethanolic Extract of Nauclea latifolia Root Bark. Journal of Herbs, Spices and Medicinal Plants, 3(2): 23-53. 1995.

[10] J. Kerharo. Historic and Ethanopharmacognosic Review on the Belief and Traditional Practices in the Treatment of Sleeping Sickness in West Africa. Bulletin of Social and Medical African Noire Lang FR. 19, 400. 1974.

[11] P.I. Akabue, G.C. Mittal. Clinical Evaluation of a Traditional Herbal Practice in Nigeria, Preliminary Report. Journal of Ethnopharmacology, 6(3): 355-359. 1982.

[12] O.I. Asubiojo, V.P. Guinn, A. Okunuga. Multi-element Analysis of Nigeria Chewing Sticks by Instrumental Neuron Activation Analysis. Journal of Radiology and Analytical Chemistry, 74, 149-156. 1982.

[13] A.A. Elujoba. Female Infertility in the Hands of Traditional Birth Attendants in South-West Nigeria. Fitoterapia, 66(3): 239-248. 1995.

[14] S.A. Adesegun, H.A.B. Coker. Plants used in Traditional Medicine in Nigeria. Journal of Pharmacology, 32, 50-62. 2001.

[15] C. Fernandez de la pradilla . Plantes Medicinales Contre les Hepatitis: 51 Especes Traopicales. Ouagadougou: Polygram Educationaire Librairie Jeunesse d' Afrique, p. 61. 1982a.

[16] M.E. Lamidi, R. Oliver, L. Faurel. L. Debravwer, E. Nze, G. Balandsard. Quinovic Acid Glycosides from Nauclea Diderichic. Planta Medica, 61, 280-281. 1995.

[17] M. Iwu. Handbook of African Medicinal Plants, $2^{\text {nd }}$ edition, Boca Raton, FL: CRC Press, pp. 28-31. 1993.

[18] Y.B. Chiao, D.H. Vanthiel. Mechanisms that Contribute to Alcoholinduced Hypogonadism in the Male. Alcoholism: Clinical and Experimental Research. 7(2): 131-134.1983.

[19] American Physiological Society. Guiding Principles for Research Involving Animals and Human beings. American Journal of Physiological Regulatory Comprehensive Physiology, 283, 281-283. 2002.

[20] M.S. Joshi, R.Y. Ambaye. Effect of Alkaloids from Vincarosea L. on Spermatogenesis in Male Rats. Indian Journal of Experimental Biology, 6, 256-257. 1968.

[21] S.C. D' Cruz, P.P. Mathur. Effect of Piperine on the Epididymis of Adult Male Rats. Asian Journal of Andrology, 7, 365 -368. 2005.

[22] F. Le Gac, H. Attramadal, T. Johnsen, V. Hansson. Studies on the Mechanism of Follicle Stimulating Hormone Induces Desensitization of Sertoli Cell Adenylyl Cyclase In Vitro. Biology of Reproduction, 32, 916-924. 1985.

[23] V. Piketty, E. Kara, F. Guillou, E. Reiter, P., Crepieux. Follicle Stimulating Hormone (FSH) Activates Extracellular Signal-regulated Kinase Phosphorylation Independently of Beta-arresting and Dynamicmediated FSH Receptor Internalization. Reproductive Biology and Endocrinology, 4, 33. 2006.

[24] M.J. Lohse, C. Krasel, R. Winstel, F. Mayor Jr. G-protein Coupled Receptor Kinases. Journal of Urology, 49, 1047-1052. 1996.

[25] P. Grasso, L.E. Reichert. Follicle Stimulating Hormone (FSH) Induces G Protein Dissociation from FSH Receptor G Protein complexes in Reconstituted proteoliposomes. Biochemical and Biophysiological Research Communication, 162, 1214-1221. 1989.

[26] L.B. Russel, J.A. Russell, G.R. Mac Gregor, M. Melstricli. Linkage of Manchette Microtubules to the Nuclear Envelope and Observations of the Role of Manchette in Nuclear Shaping during Spermiogenesis in Rodents. Journal of Anatomy, 192, 97-120. 1991.

[27] A.O. Sofola. Textbook of Human Physiology: $10^{\text {th }}$ edition, New York: Raven Press, 3, 87-873. 2001.

[28] H. Mohri, D. A. Suter, P. D. Brown-Woodman, I.G. White, D.D. Ridley. Identification of the Biochemical Lesion Produced by Alphachlorhydrin in Spermatozoa. Nature, 255(5503): 75-77. 1975.

[29] N. C. Bennett, R. A. Gardiner, J. D. Hooper, D.W. Johnson, G. C. Gobe. Molecular Cell Biology of Androgen Receptor Signaling. International Journal of Biochemistry and Cell Biology, 42 (6): 813825. 2010.

[30] Mowszanic Anti-androgens: Mechanisms and Paradoxical Effects. Annual Endocrinology, 50 (3):189-199. 1989.
[31] C. C. Zouboulis, T. Rabe. Hormonal Anti-androgens in Gene Treatment. Journal of the German Society of Dermatology, 8 (suppl): 560-574. 2010. 